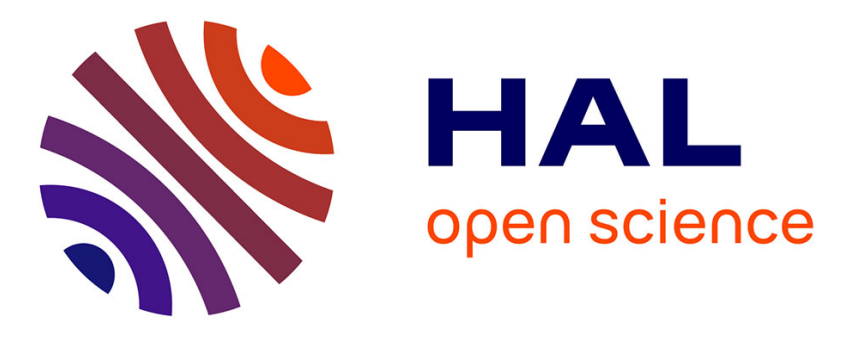

\title{
The Relationships Between Skeletal Muscle Index and Bone Variables in a Group of Young Adults
}

Anthony Khawaja, Patchina Sabbagh, Jacques Prioux, Gautier Zunquin, Georges Baquet, Ghassan Maalouf, Zaher El Hage, Amal Antoun, Rawad El Hage

\section{To cite this version:}

Anthony Khawaja, Patchina Sabbagh, Jacques Prioux, Gautier Zunquin, Georges Baquet, et al.. The Relationships Between Skeletal Muscle Index and Bone Variables in a Group of Young Adults. Journal of Clinical Densitometry, 2021, 24 (1), pp.78-87. 10.1016/j.jocd.2019.02.007 • hal-02088127

HAL Id: hal-02088127

https://hal-univ-rennes1.archives-ouvertes.fr/hal-02088127

Submitted on 17 Apr 2019

HAL is a multi-disciplinary open access archive for the deposit and dissemination of scientific research documents, whether they are published or not. The documents may come from teaching and research institutions in France or abroad, or from public or private research centers.
L'archive ouverte pluridisciplinaire HAL, est destinée au dépôt et à la diffusion de documents scientifiques de niveau recherche, publiés ou non, émanant des établissements d'enseignement et de recherche français ou étrangers, des laboratoires publics ou privés. 
The Relationships Between Skeletal Muscle Index and Bone Variables in a Group of Young Adults

Article type: Original research manuscript

Anthony Khawaja ${ }^{1,2}$, Patchina Sabbagh ${ }^{1,3}$, Jacques Prioux ${ }^{2}$, Gautier Zunquin ${ }^{4}$, Georges Baquet $^{3}$, Ghassan Maalouf ${ }^{5}$, Zaher El Hage ${ }^{6}$, Amal Antoun $^{1,7}$, Rawad El Hage ${ }^{1}$

1. Department of Physical Education, Division of Education, Faculty of Arts and Sciences, University of Balamand, Kelhat El-Koura, Lebanon.

2. Movement, Sport, and Health Sciences Laboratory (M2S), UFR-STAPS, University of Rennes 2, Rennes, France.

3. University of Lille, EA 7369 - URePSSS - Unité de Recherche Pluridisciplinaire Sport Santé Société, Ronchin, France.

4. Unité de Recherche Pluridisciplinaire Sport, Santé, Société (URePSSS-EA 7369), University of the Littoral Opal Coast, Dunkerque, France.

5. Bellevue University Medical Center, Faculty of Medicine, Saint Joseph University, Mansourieh, Lebanon.

6. Department of Psychology, Education and Physical Education, Faculty of Humanities, Notre Dame University, Lebanon.

7. Laboratoire Impact de I'Activité Physique sur la Santé (IAPS), Université de Toulon, CS 60584- 83041 TOULON CEDEX 9, France.

Corresponding author: Rawad El Hage

E-mail address: rawadelhage21@hotmail.com 
Tel.: 00961/3/713605

Fax: 00961/6/930278

Department of Physical Education, Division of Education, Faculty of Arts and Sciences, University of Balamand, P.O. Box 100 Tripoli, Lebanon.

\section{Abstract}

The purpose of this study was to investigate the relationships between skeletal muscle index (SMI) and bone variables in a group of young adults. Three hundred and thirty-five young adults (129 men and 206 women) whose ages ranged from 18 to 35 years voluntarily participated in this study. Weight and height were measured, and body mass index (BMI) was calculated. Body composition, bone mineral content (BMC), bone mineral density (BMD), geometric indices of hip bone strength and trabecular bone score (TBS) were determined for each individual by Dual-energy X-ray absorptiometry (DXA). Appendicular skeletal mass (ASM, in $\mathrm{Kg}$ ) was calculated by summing the muscle masses of the four limbs, assuming that all non-fat and none-bone mass is skeletal muscle. Skeletal muscle index (SMI) was defined as ASM / height ${ }^{2}$. In young men, SMI was positively correlated to WB BMC ( $r=$ 0.63; $p<0.001)$, WB BMD $(r=0.53 ; p<0.001)$, L1-L4 BMC $(r=0.33 ; p<0.001)$, L1-L4 BMD ( $r$ $=0.30 ; p<0.001)$, L1-L4 TBS $(r=0.26 ; p<0.01)$, TH BMC $(r=0.61 ; p<0.001)$, TH BMD $(r=$ 0.46; $\mathrm{p}<0.001)$, FN BMC $(r=0.51 ; p<0.001)$, FN BMD $(r=0.46 ; p<0.001)$, FN crosssectional area $(\mathrm{CSA})(r=0.56 ; p<0.001)$, FN cross-sectional moment of inertia (CSMI) $(r=$ $0.52 ; p<0.001)$ and FN section modulus $(Z)(r=0.54 ; p<0.001)$ but negatively correlated to FN strength index (SI) $(r=-0.24 ; p<0.01)$. In young women, SMI was positively correlated to WB BMC $(r=0.61 ; p<0.001)$, WB BMD $(r=0.60 ; p<0.001)$, L1-L4 BMC $(r=0.35 ; p<0.001)$, 
L1-L4 BMD ( $r=0.33 ; p<0.001)$, L1-L4 TBS $(r=0.29 ; p<0.001)$, TH BMC $(r=0.61 ; p<0.001)$, TH BMD $(r=0.53 ; p<0.001)$, FN BMC $(r=0.45 ; p<0.001)$, FN BMD $(r=0.49 ; p<0.001)$, FN CSA ( $r=0.60 ; p<0.001)$, FN CSMI $(r=0.52 ; p<0.001)$ and FN Z $(r=0.40 ; p<0.001)$ but negatively correlated to FN SI $(r=-0.20 ; p<0.01)$. The current study suggests that SMI is a positive determinant of bone mineral density and geometric indices of hip bone strength in young adults.

Keywords: Appendicular skeletal mass; DXA; Peak bone mass.

\section{Introduction}

Sarcopenia is a condition increasingly recognized as an extremely important public health problem (1). Because of its largely demonstrated link to poor quality of life, increased risk of mortality, mobility disability and risk of hospitalization, sarcopenia currently has and will continue to have a dramatic impact in the future on public health (1-3). Etymologically, the term "sarcopenia" comes from the Greek, "sarx" (meat) and "penia" (loss) (4). Sarcopenia is defined as the reduction of skeletal muscle mass with advancing age. It was defined in 1989 by Irwin Rosenberg (5). Muscle mass (MM) decreases with age; after the age of 40 , studies have shown an annual decline of approximately $1 \%$ (3). The size and number of type II muscle fibers gradually decrease after the age of 25 , which causes a gradual decrease in total MM of approximately $40 \%$ between the ages of 25 and 80 (6). The loss in MM with ageing may be associated with increased body fat so that despite normal weight there is marked weakness, this is a condition called sarcopenic obesity (1). In fact, the relationship between age-related reduction of $\mathrm{MM}$ and strength is often independent of body mass (1). According to Portero and Couillandre (7), the origin of sarcopenia is multifactorial; quality of life is affected by a reduction in muscle strength and muscle endurance. Thus, an increased difficulty in being physically active has been observed among older people (7). 
The definition of sarcopenia (decreased muscle mass) has evolved. Currently, it is defined by the decrease in MM (on biphotonic absorptiometry [DEXA] or CT scanner mainly) and muscle strength (evaluated by hand grip) (8-13). It is associated with a decrease in physical performance among young adults, which results in a decrease in autonomy and "fragility" (813). An individual is classified as sarcopenic when his/her skeletal muscle index (SMI) which is the equivalent of appendicular lean mass / height ${ }^{2}\left(\mathrm{ALM} / \mathrm{ht}^{2}\right)$ is two standard deviations below the mean $\mathrm{ALM} / \mathrm{ht}^{2}$ of the young reference population (14-16). Therefore, $\mathrm{SMI}$ is the main criterion to diagnose sarcopenia (14-16).

The pathophysiology and etiology of sarcopenia and osteoporosis and the relationship between them are complex and multifactorial (2). Recent studies have demonstrated that muscle and bone share some common genetic, nutritional, lifestyle, and hormonal features (2). They also showed a correlation between body composition and muscle strength with bone density (2). In addition, some determinants may influence bone through body composition, and various bone mineral density (BMD) determinants also influence body fat or MM (2). There is also evidence of a mechanistic interrelationship between muscle and bone in sarcopenic population with a higher risk of osteoporosis and vice versa (17). The relationship between these two pathologies could be established at a younger age; a positive association between skeletal muscle index (SMI) and BMD might be present in young adults.

The relationships between SMI and bone variables in young adults needs to be elucidated since most of the studies were conducted in elderly subjects. The purpose of this study was to investigate the relationships between SMI and bone variables (Bone mineral content (BMC), BMD, hip geometric indices and trabecular bone score (TBS)) in a group of young adults. We hypothesized that SMI would be significantly associated with bone variables in 
both sexes. Identification of new determinants of BMC, BMD, hip geometric indices and TBS in young adults would allow screening and early management of future cases of osteopenia and osteoporosis.

\section{Materials and Methods}

\section{Subjects and Study Design}

Three hundred and thirty-five young adults whose ages ranged from 18 to 35 years voluntarily participated in the present study. They were divided into two groups: 129 young men and 206 young women. All participants were nonsmokers and had no history of major orthopedic problems or other disorders known to affect bone metabolism. Pregnant women, amenorrheic, and those taking medications that may affect bone and calcium metabolism (corticosteroid or anticonvulsant therapy) were excluded from the study. All participants completed an interview about medical history including menstrual history and medication use. The work described has been carried out in accordance with the declaration of Helsinki (regarding human experimentation developed for the medical community by the World Medical Association). Other inclusion criteria included no diagnosis of comorbidities and no history of fracture. An informed written consent was obtained from the participants. The current study was approved by the University of Balamand Ethics Committee.

\section{Anthropometrics}

Height (in centimeters) was measured in the upright position to the nearest $1 \mathrm{~mm}$ with a standard stadiometer. Body weight (in kilograms) was measured on a mechanic scale with a precision of $100 \mathrm{~g}$. Subjects were weighed wearing only underclothes. Body mass index (BMI) was calculated as body weight divided by height squared (in kilogram per square 
meter) (18). Body composition including lean mass (LM; $\mathrm{Kg}$ ) and fat mass (FM; \%, $\mathrm{Kg}$ ) was evaluated by dual-energy X-ray absorptiometry (DXA; GE Healthcare, Madison, WI).

\section{Bone Variables}

$\mathrm{BMC}$ (in grams) and BMD (in grams per square centimeter) were determined for each individual by Dual-energy X-ray absorptiometry (DXA; GE Healthcare, Madison, WI) at the whole body (WB), lumbar spine (L1-L4), total hip (TH), and femoral neck (FN; GE Healthcare). FN cross-sectional area (CSA), strength index (SI), buckling ratio (BR), FN section modulus (Z), cross-sectional moment of inertia (CSMI) and L1-L4 TBS were also evaluated by DXA (19-21). The TBS is derived from the texture of the DXA image and has been shown to be related to bone microarchitecture and fracture risk. The TBS score can assist the healthcare professional in assessing fracture risk $(20,21)$. In our laboratory, the coefficients of variation were less than $1 \%$ for $\mathrm{BMC}$ and $\mathrm{BMD}$ and less than $3 \%$ for FN CSA (22-25). The same certified technician performed all analyses using the same technique for all measurements.

\section{Skeletal Muscle Index}

Appendicular skeletal mass (ASM, in Kg) was calculated by summing the muscle masses of the four limbs, assuming that all non-fat and none-bone mass is skeletal muscle. SMI was defined as ASM / height ${ }^{2}$ (26). A skeletal muscle mass index (SMI) $<5.5 \mathrm{~kg} / \mathrm{m}^{2}$ for women and a SMI $<7.26 \mathrm{~kg} / \mathrm{m}^{2}$ for men were defined as the cut-off points for sarcopenia (26). These cut-off points have been chosen by the European Working Group on Sarcopenia in Older People to define sarcopenia in both genders (26).

\section{Statistical Analysis}

The means and standard deviations were calculated for all clinical data and for the bone measurements. Intersex differences were specified by Student's t-test. Associations between 
SMI and bone variables were given as Pearson correlation coefficients and $r$ values were reported. Multiple linear regression analysis models were used to test the relationship of SMI and FM with bone variables, and $R^{2}$ values were reported. Statistical analyses were performed using the SigmaStat 3.1 Program (Jandel Corp., San Rafael, CA). A level of significance of $p<0.05$ was used.

\section{Results}

\section{Clinical Characteristics and Bone Data of the Study Population}

Mean values of age, weight, height, BMI, LM, FM, FM percentage, bone variables and SMI are shown in Table 1. 33 women and 7 men were sarcopenic. Age, FM, L1-L4 TBS, BR and FN SI were not significantly different between men and women. Weight, height, BMI, LM, BMC, $B M D, F N C S A, F N C S M I, F N Z$ and SMI were significantly higher in men than in women. FM percentage was significantly higher in women compared to men.

\section{Correlations Between Clinical Characteristics and Bone Variables in young men}

SMI was positively correlated to WB BMC $(r=0.63 ; p<0.001)$, WB BMD $(r=0.53 ; p<0.001)$, L1-L4 BMC ( $r=0.33 ; p<0.001)$, L1-L4 BMD $(r=0.30 ; p<0.001)$, L1-L4 TBS $(r=0.26 ; p<0.01)$, TH BMC $(r=0.61 ; p<0.001)$, TH BMD $(r=0.46 ; p<0.001)$, FN BMC $(r=0.51 ; p<0.001)$, FN $\operatorname{BMD}(r=0.46 ; p<0.001)$, FN CSA $(r=0.56 ; p<0.001)$, FN CSMI $(r=0.52 ; p<0.001)$ and FN Z $(r=0.54 ; p<0.001)$. SMI was negatively correlated to FN SI $(r=-0.24 ; p<0.01)$. LM was positively correlated to WB BMC ( $r=0.80 ; p<0.001)$, WB BMD $(r=0.54 ; p<0.001)$, L1-L4 BMC $(r=0.58 ; p<0.001)$, L1-L4 BMD $(r=0.37 ; p<0.001)$, TH BMC $(r=0.69 ; p<0.001)$, TH $\operatorname{BMD}(r=0.44 ; p<0.001)$, FN BMC $(r=0.56 ; p<0.001)$, FN BMD $(r=0.46 ; p<0.001)$, FN CSA 
$(r=0.59 ; p<0.001)$, FN CSMI $(r=0.63 ; p<0.001)$ and FN Z $(r=0.63 ; p<0.001)$. LM was negatively correlated to FN SI $(r=-0.29 ; p<0.001)$. FM was positively correlated to WB BMC $(r=0.40 ; p<0.001)$, WB BMD $(r=0.32 ; p<0.001)$, TH BMC $(r=0.36 ; p<0.001)$, TH BMD $(r=$ 0.28; $p<0.01)$, FN BMC $(r=0.30 ; p<0.001)$, FN BMD $(r=0.26 ; p<0.01)$, FN CSA $(r=0.25 ; p$ $<0.01)$ and FN CSMI $(r=0.21 ; p<0.05)$. FM was negatively correlated to FN SI $(r=-0.56 ; p<$ 0.001) (Table 2).

\section{Correlations Between Clinical Characteristics and Bone Variables in young women}

SMI was positively correlated to WB BMC $(r=0.61 ; p<0.001)$, WB BMD $(r=0.60 ; p<0.001)$, L1-L4 BMC ( $r=0.35 ; p<0.001)$, L1-L4 BMD $(r=0.33 ; p<0.001)$, L1-L4 TBS $(r=0.29 ; p<$ 0.001), TH BMC $(r=0.61 ; p<0.001)$, TH BMD $(r=0.53 ; p<0.001)$, FN BMC $(r=0.45 ; p<$ $0.001)$, FN BMD $(r=0.49 ; p<0.001)$, FN CSA $(r=0.60 ; p<0.001)$, FN CSMI $(r=0.52 ; p<$ $0.001)$ and FN Z ( $r=0.40 ; p<0.001)$. SMI was negatively correlated to FN SI $(r=-0.20 ; p<$ 0.01). LM was positively correlated to WB BMC $(r=0.82 ; p<0.001)$, WB BMD $(r=0.68 ; p<$ 0.001), L1-L4 BMC ( $r=0.55 ; p<0.001)$, L1-L4 BMD ( $r=0.39 ; p<0.001)$, L1-L4 TBS $(r=0.21 ; p$ $<0.01)$, TH BMC $(r=0.76 ; p<0.001)$, TH BMD $(r=0.58 ; p<0.001)$, FN BMC $(r=0.61 ; p<$ $0.001)$, FN BMD $(r=0.60 ; p<0.001)$, FN CSA $(r=0.74 ; p<0.001)$, FN CSMI $(r=0.67 ; p<$ $0.001)$ and FN Z ( $r=0.54 ; \mathrm{p}<0.001)$. LM was negatively correlated to FN SI $(r=-0.17 ; \mathrm{p}<$ 0.05). FM was positively correlated to WB BMC $(r=0.41 ; p<0.001)$, WB BMD $(r=0.42 ; p<$ 0.001), L1-L4 BMC ( $r=0.24 ; p<0.001)$, L1-L4 BMD $(r=0.23 ; p<0.001)$, L1-L4 TBS $(r=0.22 ; p$ $<0.01)$, TH BMC $(r=0.37 ; p<0.001)$, TH BMD $(r=0.33 ; p<0.001)$, FN BMC $(r=0.28 ; p<$ 0.001), FN BMD ( $r=0.31 ; p<0.001)$, FN CSA $(r=0.42 ; p<0.001)$, FN CSMI $(r=0.39 ; p<$ $0.001)$ and FN Z ( $r=0.44 ; p<0.001)$. FM was negatively correlated to FN SI $(r=-0.29 ; p<$ 0.001) (Table 3).

\section{Multiple Linear Regressions in men}


After adjusting for FM, SMI remained positively correlated to WB BMC $(p<0.001)$, WB BMD $(p<0.001)$, L1-L4 BMC $(p<0.001)$, L1-L4 BMD $(p<0.001)$, L1-L4 TBS $(p<0.001)$, TH BMC $(p<$ 0.001), TH BMD $(p<0.001)$, FN BMC $(p<0.001)$, FN BMD $(p<0.001)$, FN CSA $(p<0.001)$, FN CSMI $(p<0.001)$ and FN Z ( $<0.001)$. SMI was a stronger determinant of L1-L4 TBS than FM. After adjusting for SMI, FM became negatively correlated to L1-L4 TBS $(p=0.011)$ and positively correlated to $B R(p=0.049)$ and remained negatively correlated to FN SI $(p<$ 0.001) (Table 4).

\section{Multiple Linear Regressions in women}

After adjusting for FM, SMI remained positively correlated to WB BMC $(p<0.001)$, WB BMD $(p<0.001)$, L1-L4 BMC $(p<0.001)$, L1-L4 BMD $(p<0.001)$, L1-L4 TBS $(p=0.006)$, TH BMC $(p<$ 0.001), TH BMD $(p<0.001), \operatorname{FN~BMC~}(p<0.001)$, FN BMD $(p<0.001), \operatorname{FN~CSA}(p<0.001)$ and FN CSMI $(p<0.001)$. After adjusting for SMI, FM remained positively correlated to FN Z ( $p=$ $0.028)$ and negatively correlated to FN SI $(p=0.001)$ and became negatively correlated to BR $(p=0.037)($ Table 5$)$.

\section{Discussion}

The current study conducted on a group of young adults mainly shows that SMI is positively correlated to BMC, BMD, TBS, FN CSA, FN CSMI, and FN Z in both sexes. Most of these associations remained significant after adjustment for fat mass.

After adjusting for FM, SMI remained positively correlated to BMC, BMD, TBS, FN CSA and FN CSMI in both sexes. This is one of few studies that used such analysis to investigate whether SMI is an independent determinant of DXA variables in young adults. Accordingly, SMI seems to be an independent determinant of bone variables in both sexes. To our 
knowledge, the present study is the first study that aimed at exploring the associations between SMI and bone variables in young adults since most of the previous studies have been conducted on older people. Interestingly, SMI was a stronger determinant of TBS than lean mass in both genders. The reasons that may explain such results remain unclear. The current study encourages the use of SMI as a new determinant of TBS in young adults. Moreover, SMI was correlated with most of the bone variables and these associations, were present in both sexes. Our results are consistent with those of many previous studies conducted on elderly subjects (3,27-31). An earlier study conducted by Hida et al. (3) demonstrated a positive correlation between appendicular skeletal muscle index and WB BMD in a group of women who did not have osteoporotic vertebral fractures. Another study conducted on a group of men aged 50 years or older found an association between appendicular skeletal mass (ASM) and FN BMD (27). Similarly, some studies (28-30) have shown that the ASM is correlated to FN BMD in adult and older men, more than leg muscle mass. In a previous work, Di Monaco et al. (31) analyzed the relation between osteoporosis and sarcopenia in three hundred and thirteen women who suffered recent fractures of the hip. They demonstrated a significant positive correlation between ALM/height ${ }^{2}$ and BMD assessed at both total proximal femur and femoral neck. $58 \%$ of the three hundred and thirteen women were sarcopenic, whereas $73 \%$ were affected by osteoporosis. They have shown a significant correlation between sarcopenia and osteoporosis. This correlation remained significant after adjustment for age. The results also revealed that the odds for osteoporosis is 1.8 higher in sarcopenic women (31). Moreover, two studies have shown positive correlations between ASM and several bone strength parameters such as BMD, bending strength and cortical thickness $(30,32)$. 
Our results confirm the positive importance of LM on bone health in young adults. In young men, $\mathrm{LM}$ is positively correlated to BMC, BMD, FN CSA, FN CSMI and FN Z, whereas LM is negatively correlated to FN SI. In young women, LM is positively correlated to BMC, BMD, TBS, FN CSA, FN CSMI and FN Z, whereas LM is negatively correlated to FN SI. LM is the main determinant of bone variables in both sexes. Accordingly, LM appears to be a predictor of BMC, BMD and hip geometric indices in young adults. Our results are in accordance with those of many previous studies that have shown that LM is an important determinant of WB BMC, FN CSA and FN Z (33-40). A study conducted on a group of overweight and obese young men confirms the positive importance of $L M$ on bone mass in overweight men (33). Similarly, LM appears to be a predictor of BMD and hip geometric indices in overweight or obese men and normal weighted men (33). In a cohort study (17,891 subjects aged from 18 to 97 years), He et al. (2) found significant positive correlations between whole-body, regional $B M D$ and $L M$. $L M$ was positively correlated to BMD at all skeletal sites (2). Genaro et al. (41) conducted a cross-sectional study that included 70 osteoporotic postmenopausal women. They demonstrated a significant correlation between LM and bone variables such as $B M C$ and $B M D$. They have suggested that FN BMD and femur BMD were correlated to $L M$ (41). In addition, a positive correlation was observed between LM and bone mass in sarcopenic population $(42,43)$.

The current study suggests that, in young men, FM is positively correlated to WB BMC, WB BMD, TH BMD, FN BMD, FN CSA and FN CSMI but negatively correlated to FN SI. Our study also suggests that, in young women, $\mathrm{FM}$ is positively correlated to BMC, BMD, TBS, FN CSA, FN CSMI and FN Z but negatively correlated to FN SI. After adjusting for SMI, FM became negatively correlated to L1-L4 TBS and positively correlated to BR and remained negatively 
correlated to $\mathrm{FN} \mathrm{SI} \mathrm{in} \mathrm{young} \mathrm{men.} \mathrm{In} \mathrm{young} \mathrm{women,} \mathrm{FM} \mathrm{remained} \mathrm{positively} \mathrm{correlated} \mathrm{to} \mathrm{FN}$ $\mathrm{Z}$ and negatively correlated to FN SI while FM became negatively correlated to BR after adjusting for SMI. The strength of the associations between fat mass and bone variables were poor in both sexes. However, based on our results, the relationships between FM and bone variables seem to be stronger in women compared to men.

Our results are in accordance with those of a previous study (44) conducted on three hundred healthy sexually mature adolescents and young adults (150 men and 150 women) between 13 and 21 years old. This study has found positive correlations between FM and DXA and computed tomography (CT) bone variables in women, while these correlations were weaker or nonexistent in men (44). Another previous study conducted on postmenopausal women has shown a significant correlation between FM and bone variables such as BMC and BMD (41). In addition, in postmenopausal women, FM was correlated to BMD at all sites (42). Two recent studies have reported an inverse relationship between body fat and BMD after controlling the effects of mechanical body weight load on bone mass $(44,45)$. Finally, Di Monaco et al. $(46,47)$, demonstrated a significant correlation between FM and BMD in elderly women with hip fracture.

Our study had some limitations. First, the cross-sectional nature of the present study is a limitation because it cannot evaluate the confounding variables. The second limitation is the 2-dimensional nature of DXA $(48,49)$. The third limitation is the disproportionality in the number of subjects in each group. The fourth limitation is the lack of physical activity level measurement. Finally, mean BMI was significantly different between men and women. However, to our knowledge, the present study is the first study that aimed at exploring the 
relationships between $\mathrm{SMI}$ and bone variables such as $\mathrm{BMC}, \mathrm{BMD}$, hip geometric indices and TBS in young adults.

In conclusion, the current study suggests that $\mathrm{SMI}$ is a positive determinant of BMC, BMD, TBS, FN CSA, FN CSMI and FN Z in young adults. Our results demonstrate also that SMI is an independent determinant of BMC, BMD, FN CSA and FN CSMI in both genders. To our knowledge, the current study is the first study that demonstrates positive correlations between SMI and bone variables in young adults. Furthermore, implementing strategies to increase SMI in young adults may be useful for preventing osteoporosis later in life. Finally, our study may be useful for the prevention and early detection of osteoporosis and osteopenia and encourages the use of SMI as a new determinant of bone variables in young adults.

\section{Acknowledgments}

This study was supported by a grant from the research council of the University of Balamand, Lebanon.

\section{Conflict of Interest}

None of the authors reported a conflict of interest related to the study.

\section{References}

1. Santilli V, Bernetti A, Mangone M, Paoloni M. 2014 Clinical definition of sarcopenia. Clin Cases Miner Bone Metab. 11(3):177-180.

2. He H, Liu Y, Tian Q, Papasian CJ, Hu T, Deng HW. 2016 Relationship of sarcopenia and body composition with osteoporosis. Osteoporos Int. 27: 473-482. 
3. Hida T, Shimokata H, Sakai Y, et al. 2016 Sarcopenia and sarcopenic leg as potential risk factors for acute osteoporotic vertebral fracture among older women. Eur Spine J. 25(11):3424-3431.

4. Malafarina V, Uriz-Otano F, Iniesta R, Gil-Guerrero L. 2012 Sarcopenia in the elderly: Diagnosis, physiopathology and treatment. Maturitas. 71: 109-114.

5. Rosenberg IH. 1989 Summary comments. Am J Clin Nutr. 26: 1231-3.

6. Beaudart C, Reginster JY, Geerinck A, Locquet M, Bruyère O. 2017 Current review of the SarQoL ${ }^{\circledR}$ : a health-related quality of life questionnaire specific to sarcopenia. Expert Rev of Pharmacoeconomics Outcomes Res. 17(4):335-341.

7. Portero P, Couillandre A. 2011 Sarcopénie de la personne âgé et réentraînement musculaire. Kinesither Rev. 109-110:61.

8. Crenn P. 2013 Sarcopénie et cachexie : approche médicamenteuse. Nutr Clin Metab. 27: $69-73$.

9. Cruz-Jentoft AJ, Baeyens JP, Bauer JM, et al. 2010 Sarcopenia: European consensus on definition and diagnosis: report of the European Working Group on sarcopenia in older people. Age Ageing. 39:412-23.

10. Muscaritoli M, Anker SD, Argiles J, et al. 2010 Consensus definition of sarcopenia, cachexia and pre-cachexia: joint document elaborated by Special Interest Groups (SIG) "cachexiaanorexia in chronic wasting diseases" and "nutrition in geriatrics". Clin Nutr. 29: $154-9$.

11. Salame M, Costa KK, Zottele LV, et al. 2015 Sarcopenia: evaluation of different diagnostic criteria and its association with muscle strength and functional capacity. Rev Bras Geriatr Gerontol Rio de Janeiro. 18(2):285-294. 
12. Marguth KMM, Schuch NJ, Schwanke CH. 2017 Inflammatory markers, sarcopenia and its diagnostic criteria among the elderly: a systematic review. Rev Bras Geriatr Gerontol Rio de Janeiro. 20(3):441-453.

13. Musumeci G. 2017 Sarcopenia and Exercise "The State of the Art". J Funct Morphol Kinesiol. 2(40):40.

14. Baumgartner RN, Koehler KM, Gallagher D, et al. 1998 Epidemiology of sarcopenia among the elderly in New Mexico. Am J Epidemiol. 147(8):755-63.

15. Gallagher D, Visser M, De Meersman RE, et al. 1997 Appendicular skeletal muscle mass: effects of age, gender, and ethnicity. J Appl Physiol. 83(1):229-39.

16. Scott D, Hayes A, Sanders KM, Aitken D, Ebeling PR, Jones G. 2014 Operational definitions of sarcopenia and their associations with 5-year changes in falls risk in community-dwelling middle-aged and older adults, Osteoporos Int. 25:187-193.

17. Edwards MH, Dennison EM, Aihie Sayer A, Fielding R, Cooper C. 2015 Osteoporosis and Sarcopenia in Older Age. Bone. 80:126-130.

18. World Health Organization. 2000 Obesity: Preventing and managing the global epidemic. WHO technical report series, Geneva.

19. Beck TJ, Ruff CB, Warden KE, LeBoff MS, Cauley JA, Chen Z. 1990 Predicting femoral neck strength from bone mineral data. A structural approach. Invest Radiol. 25(1):6-18.

20. Silva BC, Broy SB, Boutroy S, et al. 2015 Fracture risk prediction by non-BMD DXA measures: the 2015 ISCD Official Positions Part 2: trabecular bone score. J Clin Densitom. 18(3):309-330.

21. Harvey NC, Glüer CC, Binkley N, et al. 2015 Trabecular bone score (TBS) as a new complementary approach for osteoporosis evaluation in clinical practice. Bone. 78:216-224. 
22. El Hage R, Zakhem E, Theunynck D, et al. 2014 Maximal oxygen consumption and bone mineral density in a group of young Lebanese adults. J Clin Densitom. 17:320-324.

23. El Hage R, Bachour F, Sebaalt A, et al. 2014 The influence of weight status on radial bone mineral density in Lebanese women. Calcif Tissue Int. 94(4):465-467.

24. El Hage R, Bachour F, Khairallah W, et al. 2014 The influence of obesity and overweight on hip bone mineral density in Lebanese women. J Clin Densitom. 17(1):216-217.

25. Zakhem E, Ayoub MI, Zunquin G, et al. 2015 Physical performance and trabecular bone score in a group of young Lebanese women. J Clin Densitom. 18:271-272.

26. Cruz-Jentoft AJ, Baeyens JP, Bauer JM, et al. 2010 Sarcopenia: European consensus on definition and diagnosis: Report of the European Working Group on Sarcopenia in Older people. Age Ageing 39:412-23.

27. Blain H, Jaussent A, Thomas E, et al. 2010 Appendicular skeletal muscle mass is the strongest independent factor associated with femoral neck bone mineral density in adult and older men. Exp Gerontol. 45 :679-684.

28. Szulc P, Beck TJ, Marchand F, Delmas PD. 2005 Low skeletal muscle mass is associated with poor structural parameters of bone and impaired balance in elderly men-the MINOS study. J. Bone Miner Res. 20:721-729.

29. Baumgartner RN, Stauber PM, Koehler KM, Romero L, Garry PJ. 1996 Associations of fat and muscle masses with bone mineral in elderly men and women. Am J Clin Nutr. 63:365372.

30. Pluijm SM, Visser M, Smit JH, Popp-Snijders C, Roos JC, Lips P. 2001 Determinants of bone mineral density in older men and women: body composition as mediator. J Bone Miner Res. 16:2142-2151. 
31. Di Monaco M, Vallero F, Di Monaco R, Tappero R. 2011 Prevalence of sarcopenia and its association with osteoporosis in 313 older women following a hip fracture. Arch Gerontol Geriatr. 52(1):71-74.

32. Barondess DA, Nelson DA, Schlaen SE. 1997 Whole body bone, fat, and lean mass in black and white men. J Bone Miner Res. 12:967-71.

33. El Khoury C, Pinti A, Lespessailles E, et al. 2018 Physical Performance Variables and Bone Mineral Density in a Group of Young Overweight and Obese Men. J Clin Densitom. 21(1):4147.

34. Petit MA, Beck TJ, Hughes JM, Lin HM, Bentley C, Lloyd T. 2008 Proximal femur mechanical adaptation to weight gain in late adolescence: a six-year longitudinal study. J Bone Miner Res. 23:180-188.

35. Shea KL, Gozansky WS, Sherk VD, et al. 2014 Loss of bone strength in response to exercise-induced weight loss in obese postmenopausal women: results from a pilot study. J Musculoskelet Neuronal Interact. 14:229-238.

36. MacKelvie KJ, McKay HA, Petit MA, Moran O, Khan KM. 2002 Bone mineral response to a 7-month randomized controlled, school-based jumping intervention in 121 prepubertal boys: associations with ethnicity and body mass index. J Bone Miner Res. 17(5):834-844.

37. Nikander R, Sievänen H, Heinonen A, Kannus P. 2005 Femoral neck structure in adult female athletes subjected to different loading modalities. J Bone Miner Res. 20(3):520-528. 38. Lorentzon M, Mellström D, Ohlsson C. 2005 Association of amount of physical activity with cortical bone size and trabecular volumetric BMD in young adult men: the GOOD study. J Bone Miner Res. 20(11):1936-1943.

39. Bonjour JP, Chevalley T, Rizzoli R, et al. 2007 Gene environment interactions in the skeletal response to nutrition and exercise during growth. Med Sport Sci. 51:64-80. 
40. El Hage R, Jacob C, Moussa E, et al. 2009 Effects of 12 weeks of endurance training on bone mineral content and bone mineral density in obese, overweight and normal weight adolescent girls. Sci Sports. 24(3-4):210-213.

41. Genaro PS, Pereira GA, Pinheiro MM, Szejnfeld VL, Martini LA. 2010 Influence of body composition on bone mass in postmenopausal osteoporotic women. Arch Gerontol Geriatr. 51(3): 295-298.

42. Cui LH, Shin MH, Kweon SS, et al. 2007 Relative contribution of body composition to bone mineral density at different sites in men and women of South Korea. J Bone Miner Metab. 25,165-171.

43. Gnudi S, Sitta E, Fiume N. 2007 Relationship between body composition and bone mineral density in women with and without osteoporosis: relative contribution of lean and fat mass. J Bone Miner Metab. 25,326-332.

44. Janicka A, Wren TA, Sanchez MM, et al. 2007 Fat mass is not beneficial to bone in adolescents and young adults. J Clin Endocrinol Metab. 92(1):143-147.

45. Taes YE, Lapauw B, Vanbillemont G, et al. 2009 Fat mass is negatively associated with cortical bone size in young healthy male siblings. J Clin Endocrinol Metab. 94(7):2325-2331.

46. Di Monaco M, Vallero F, Di Monaco R, Tappero R, Cavanna A. 2007 Skeletal muscle mass, fat mass, and hip bone mineral density in elderly women with hip fracture. J Bone Miner Metab. 25(4):237-242.

47. Di Monaco M, Vallero F, Di Monaco R, Tappero R, Cavanna A. 2007 Fat mass and skeletal muscle mass in hip-fracture women: a cross-sectional study. Maturitas. 56(4):404-410.

48. Beck TJ. 2003 Measuring the structural strength of bones with dual-energy X-ray absorptiometry: principles, technical limitations, and future possibilities. Osteoporos Int. 14(Suppl 5):S81-S88. 
49. Beck TJ. 2007 Extending DXA beyond bone mineral density: understanding hip structure analysis. Curr Osteoporos Rep. 5(2):49-55.

Table 1: Physical Characteristics of the Study Population

\begin{tabular}{|c|c|c|}
\hline Characteristics & Men $(n=129)$ & Women $(n=206)$ \\
\hline & Mean \pm SD & Mean \pm SD \\
\hline Age (yr) & $24.3 \pm 4.8$ & $24.0 \pm 3.9$ \\
\hline Weight (kg) & $000+200 *$ & $65.0 \pm 14.0$ \\
\hline Height (m) & $1.75 \pm 0.07 * * *$ & $1.61 \pm 0.06$ \\
\hline BMI $\left(\mathrm{kg} / \mathrm{m}^{2}\right)$ & $\pm 5.8 * * *$ & $24.8 \pm 5.0$ \\
\hline Lean Mass (kg) & $530 \pm 8.850 * * *$ & $38.412 \pm 6.399$ \\
\hline Fat Mass (kg) & $26.714 \pm 14.889$ & $24.673 \pm 9.159$ \\
\hline Fat Mass $\%$ & $27.2 \pm 8.7 * * *$ & $36.6 \pm 6.7$ \\
\hline WB BMC (g) & $3076 \pm 419 * * *$ & $2241 \pm 325$ \\
\hline WB BMD $\left(\mathrm{g} / \mathrm{cm}^{2}\right)$ & $1.238 \pm 0.121 * * *$ & $1.086 \pm 0.101$ \\
\hline L1-L4 BMC (g) & $74.2 \pm 14.5^{* * *}$ & $59.3 \pm 9.9$ \\
\hline L1-L4 BMD (g/cm²) & $1.210 \pm 0.157 * * *$ & $1.144 \pm 0.127$ \\
\hline L1-L4 TBS & $1.408 \pm 0.111$ & $1.425 \pm 0.102$ \\
\hline
\end{tabular}




\begin{tabular}{|l|c|c|}
\hline TH BMC (g) & $40.6 \pm 6.8^{* * *}$ & $28.6 \pm 5.5$ \\
\hline TH BMD $\left(\mathrm{g} / \mathrm{cm}^{2}\right)$ & $1.132 \pm 0.146^{* * *}$ & $0.997 \pm 0.130$ \\
\hline FN BMC (g) & $6.10 \pm 1.08^{* * *}$ & $4.51 \pm 0.88$ \\
\hline FN BMD $\left(\mathrm{g} / \mathrm{cm}^{2}\right)$ & $1.136 \pm 0.159^{* * *}$ & $0.956 \pm 0.144$ \\
\hline FN CSA $\left(\mathrm{mm}^{2}\right)$ & $196.6 \pm 30.6^{* * *}$ & $145.8 \pm 25.8$ \\
\hline FN CSMI $\left(\mathrm{mm}^{2}\right)^{2}$ & $17673 \pm 4626^{* * *}$ & $10120 \pm 3312$ \\
\hline FN Z $\left(\mathrm{mm}{ }^{3}\right)$ & $955 \pm 230^{* * *}$ & $572 \pm 126$ \\
\hline BR & $5.883 \pm 2.574$ & $6.947 \pm 4.295$ \\
\hline FN SI & $1.587 \pm 0.411$ & $1.651 \pm 0.441$ \\
\hline SMI $\left(\mathrm{kg} / \mathrm{m}^{2}\right)$ & $9.224 \pm 1.216^{* * *}$ & $6.551 \pm 1.128$ \\
\hline
\end{tabular}

$\mathrm{BMI}$, body mass index; $\mathrm{WB}$, whole body; $\mathrm{BMC}$, bone mineral content; $\mathrm{BMD}$, bone mineral density; TBS, trabecular bone score; L1-L4, Lumbar spine; TH, total hip; FN, femoral neck; CSA, cross-sectional area; CSMI, cross-sectional moment of inertia; Z, section modulus; BR, buckling ratio; $\mathrm{SI}$, strength index, SMI, skeletal muscle index; SD, standard deviation. ${ }^{*} p<$ $0.05 ; * p<0.01 ; * * * p<0.001$ 
Table 2: Correlations Between Clinical Characteristics and Bone Variables in Young Men

\begin{tabular}{|c|c|c|c|c|c|c|c|c|c|c|c|c|c|c|}
\hline$N=129$ & $\begin{array}{c}\text { WB } \\
\text { BMC } \\
\text { (g) }\end{array}$ & $\begin{array}{c}\text { WB } \\
\text { BMD } \\
\left(\mathrm{g} / \mathrm{cm}^{2}\right)\end{array}$ & $\begin{array}{l}\text { L1-L4 } \\
\text { BMC } \\
\text { (g) }\end{array}$ & $\begin{array}{c}\text { L1-L4 } \\
\text { BMD } \\
\left(\mathrm{g} / \mathrm{cm}^{2}\right)\end{array}$ & $\begin{array}{c}\text { L1-L4 } \\
\text { TBS }\end{array}$ & $\begin{array}{r}\text { TH } \\
\text { BMC } \\
\text { (g) }\end{array}$ & $\begin{array}{c}\text { TH } \\
\text { BMD } \\
\left(\mathrm{g} / \mathrm{cm}^{2}\right)\end{array}$ & $\begin{array}{c}\mathrm{FN} \\
\text { BMC } \\
\text { (g) }\end{array}$ & $\begin{array}{c}\mathrm{FN} \\
\mathrm{BMD} \\
\mathrm{g} / \mathrm{cm}^{2}\end{array}$ & $\begin{array}{c}\mathrm{FN} \\
\mathrm{CSA} \\
\left(\mathrm{mm}^{2}\right)\end{array}$ & $\begin{array}{c}\text { FN } \\
\text { CSMI } \\
\left(\mathrm{mm}^{2}\right)^{2}\end{array}$ & $\begin{array}{c}\mathrm{FN} \mathrm{Z} \\
\left(\mathrm{mm}^{3}\right)\end{array}$ & BR & FN SI \\
\hline $\begin{array}{l}\text { Age } \\
\text { (yr) }\end{array}$ & -0.06 & -0.07 & 0.07 & -0.04 & -0.09 & $\begin{array}{c}-0.19 \\
*\end{array}$ & $\begin{array}{c}-0.24 \\
* *\end{array}$ & & & $\begin{array}{c}-0.26 \\
* *\end{array}$ & $\begin{array}{c}-0.17 \\
*\end{array}$ & $\begin{array}{c}-0.29 \\
*\end{array}$ & 0.01 & -0.07 \\
\hline $\begin{array}{c}\text { Weight } \\
\text { (kg) }\end{array}$ & $\begin{array}{l}0.63 \\
* * *\end{array}$ & $\begin{array}{l}0.45 \\
* * *\end{array}$ & $\begin{array}{c}0.30 \\
* *\end{array}$ & 0.18 & 0.05 & $\begin{array}{l}0.53 \\
* * *\end{array}$ & & & $\begin{array}{l}0.36 \\
* * *\end{array}$ & $\begin{array}{l}0.42 \\
* * *\end{array}$ & $\begin{array}{l}0.42 \\
* * *\end{array}$ & $\begin{array}{l}0.41 \\
* * *\end{array}$ & 0.12 & $\begin{array}{l}-0.51 \\
* * *\end{array}$ \\
\hline $\begin{array}{c}\text { Height } \\
\text { (m) }\end{array}$ & $\begin{array}{l}0.58 \\
* * *\end{array}$ & $\begin{array}{c}0.20 \\
*\end{array}$ & $\begin{array}{l}0.49 \\
* * *\end{array}$ & 0.19 & -0.06 & 0.37 & 0.13 & $\begin{array}{l}0.31 \\
* * *\end{array}$ & $\begin{array}{c}0.19 \\
*\end{array}$ & $\begin{array}{l}0.31 \\
* * *\end{array}$ & $\begin{array}{l}0.42 \\
* * *\end{array}$ & $\begin{array}{l}0.42 \\
* * *\end{array}$ & -0.10 & $\begin{array}{c}-0.23 \\
* *\end{array}$ \\
\hline $\begin{array}{c}\text { BMI } \\
\left(\mathrm{kg} / \mathrm{m}^{2}\right)\end{array}$ & $\begin{array}{l}0.46 \\
* * *\end{array}$ & $\begin{array}{l}0.42 \\
* * *\end{array}$ & 0.11 & 0.12 & & 0.43 & $\begin{array}{l}0.35 \\
* * *\end{array}$ & $\begin{array}{l}0.34 \\
* * *\end{array}$ & $\begin{array}{l}0.32 \\
* * *\end{array}$ & $\begin{array}{l}0.34 \\
* * *\end{array}$ & $\begin{array}{l}0.29 \\
* * *\end{array}$ & $\begin{array}{c}0.27 \\
*\end{array}$ & 0.17 & $\begin{array}{c}-0.48 \\
* * *\end{array}$ \\
\hline FM (kg) & $\begin{array}{l}0.40 \\
* * *\end{array}$ & $\begin{array}{l}0.32 \\
* * *\end{array}$ & 0.03 & & -0.03 & $\begin{array}{l}0.36 \\
* * *\end{array}$ & $\begin{array}{c}0.28 \\
* *\end{array}$ & $\begin{array}{l}0.30 \\
* * *\end{array}$ & $\begin{array}{c}0.26 \\
* *\end{array}$ & $\begin{array}{c}0.25 \\
* *\end{array}$ & $\begin{array}{c}0.21 \\
*\end{array}$ & 0.21 & 0.19 & $\begin{array}{l}-0.56 \\
* * *\end{array}$ \\
\hline FM \% & 0.22 & 0.20 & & -0.02 & -0.09 & 0.15 & 0.15 & 0.12 & 0.14 & 0.08 & 0.02 & -0.01 & 0.27 & -0.59 \\
\hline
\end{tabular}




\begin{tabular}{|c|c|c|c|c|c|c|c|c|c|c|c|c|c|c|}
\hline & $*$ & $*$ & & & & & & & & & & $y^{*}$ & $* *$ \\
\hline $\mathbf{L M}(\mathrm{Kg})$ & 0.80 & 0.54 & 0.58 & 0.37 & 0.17 & 0.69 & 0.44 & 0.56 & 0.46 & 0.59 & 0.63 & 0.63 & -0.03 & -0.29 \\
& $* * *$ & $* * *$ & $* * *$ & $* * *$ & & $* * *$ & $* * *$ & $* * *$ & $* * *$ & $* * *$ & $* * *$ & $* * *$ & $* *$ \\
\hline $\mathbf{S M I}$ & 0.63 & 0.53 & 0.33 & 0.30 & 0.26 & 0.61 & 0.46 & 0.51 & 0.46 & 0.56 & 0.52 & 0.54 & -0.05 & -0.24 \\
$\mathbf{( k g / \mathbf { m } ^ { 2 } )}$ & $* * *$ & $* * *$ & $* * *$ & $* * *$ & $* *$ & $* * *$ & $* * *$ & $* * *$ & $* * *$ & $* * *$ & $* * *$ & $* * *$ & $* *$ \\
& & & & & & & & & & & & & &
\end{tabular}

BMI, body mass index; FM, fat mass; LM, lean mass; SMI, skeletal muscle index; WB, whole body; BMC, bone mineral content; BMD, bone mineral density; TBS, trabecular bone score; L1-L4, Lumbar spine; TH, total hip; FN, femoral neck; CSA, cross-sectional area; CSMI, crosssectional moment of inertia; Z, section modulus; BR, buckling ratio; SI, strength index. ${ }^{*} p<0.05 .{ }^{* *} p<0.01 .{ }^{* * *} p<0.001$. 
Table 3: Correlations Between Clinical Characteristics and Bone Variables in Young Women

\begin{tabular}{|c|c|c|c|c|c|c|c|c|c|c|c|c|c|c|}
\hline$N=206$ & $\begin{array}{c}\text { WB } \\
\text { BMC } \\
\text { (g) }\end{array}$ & $\begin{array}{c}\text { WB } \\
\text { BMD } \\
\left(\mathrm{g} / \mathrm{cm}^{2}\right)\end{array}$ & $\begin{array}{c}\text { L1-L4 } \\
\text { BMC } \\
\text { (g) }\end{array}$ & $\begin{array}{c}\text { L1-L4 } \\
\text { BMD } \\
\left(\mathrm{g} / \mathrm{cm}^{2}\right)\end{array}$ & $\begin{array}{c}\text { L1-L4 } \\
\text { TBS }\end{array}$ & $\begin{array}{c}\text { TH } \\
\text { BMC } \\
\text { (g) }\end{array}$ & $\begin{array}{c}\text { TH } \\
\text { BMD } \\
\left(\mathrm{g} / \mathrm{cm}^{2}\right)\end{array}$ & $\begin{array}{c}\text { FN } \\
\text { BMC } \\
\text { (g) }\end{array}$ & $\begin{array}{c}\mathrm{FN} \\
\mathrm{BMD} \\
\mathrm{g} / \mathrm{cm}^{2}\end{array}$ & $\begin{array}{l}\text { FN CSA } \\
\left(\mathrm{mm}^{2}\right)\end{array}$ & $\begin{array}{l}\mathrm{FN} \\
\mathrm{CSMI} \\
\left(\mathrm{mm}^{2}\right)^{2}\end{array}$ & $\begin{array}{c}\mathrm{FN} \mathrm{Z} \\
\left(\mathrm{mm}^{3}\right)\end{array}$ & BR & FN S \\
\hline $\begin{array}{l}\text { Age } \\
\text { (yr) }\end{array}$ & 0.03 & 0.03 & -0.01 & -0.01 & -0.11 & -0.03 & -0.11 & & -0.15 & -0.04 & 0.08 & 0.11 & 0.02 & -0.08 \\
\hline $\begin{array}{c}\text { Weight } \\
\text { (kg) }\end{array}$ & $\begin{array}{l}0.67 \\
* * *\end{array}$ & $\begin{array}{l}0.62 \\
* * *\end{array}$ & $\begin{array}{l}0.44 \\
* * *\end{array}$ & $\begin{array}{l}0.35 \\
* * *\end{array}$ & $\begin{array}{l}0.29 \\
* * *\end{array}$ & $\begin{array}{l}0.63 \\
* * *\end{array}$ & & 0.51 & $\begin{array}{l}0.52 \\
* * *\end{array}$ & $\begin{array}{l}0.65 \\
* * *\end{array}$ & $\begin{array}{l}0.59 \\
* * *\end{array}$ & $\begin{array}{l}0.52 \\
* * *\end{array}$ & -0.12 & $\begin{array}{r}-0.26 \\
* * *\end{array}$ \\
\hline $\begin{array}{c}\text { Height } \\
\text { (m) }\end{array}$ & $\begin{array}{l}0.57 \\
* * *\end{array}$ & $\begin{array}{l}0.27 \\
* * *\end{array}$ & $\begin{array}{l}0.40 \\
* * *\end{array}$ & 0.13 & -0.15 & 0.44 & 0.23 & $\begin{array}{l}0.39 \\
* * *\end{array}$ & $\begin{array}{l}0.33 \\
* * *\end{array}$ & $\begin{array}{l}0.41 \\
* * *\end{array}$ & $\begin{array}{l}0.38 \\
* * *\end{array}$ & $\begin{array}{c}0.33 \\
* *\end{array}$ & -0.15 & -0.11 \\
\hline $\begin{array}{c}\text { BMI } \\
\left(\mathrm{kg} / \mathrm{m}^{2}\right)\end{array}$ & $\begin{array}{l}0.47 \\
* * *\end{array}$ & $\begin{array}{l}0.53 \\
* * *\end{array}$ & $\begin{array}{l}0.29 \\
* * *\end{array}$ & 0.32 & & 0.47 & $\begin{array}{l}0.44 \\
* * *\end{array}$ & $\begin{array}{l}0.37 \\
* * *\end{array}$ & $\begin{array}{l}0.41 \\
* * *\end{array}$ & $\begin{array}{l}0.51 \\
* * *\end{array}$ & $\begin{array}{l}0.45 \\
* * *\end{array}$ & $\begin{array}{l}0.44 \\
* * *\end{array}$ & -0.08 & $\begin{array}{r}-0.24 \\
* * *\end{array}$ \\
\hline FM (kg) & $\begin{array}{l}0.41 \\
* * *\end{array}$ & $\begin{array}{l}0.42 \\
* * *\end{array}$ & 0.24 & & 0.22 & $\begin{array}{l}0.37 \\
* * *\end{array}$ & $\begin{array}{l}0.33 \\
* * *\end{array}$ & $\begin{array}{l}0.28 \\
* * *\end{array}$ & $\begin{array}{l}0.31 \\
* * *\end{array}$ & $\begin{array}{l}0.42 \\
* * *\end{array}$ & $\begin{array}{l}0.39 \\
* * *\end{array}$ & $\begin{array}{l}0.44 \\
* * *\end{array}$ & -0.13 & $\begin{array}{l}-0.29 \\
* * *\end{array}$ \\
\hline FM \% & 0.08 & 0.18 & & 0.11 & 0.18 & 0.08 & 0.14 & 0.07 & 0.11 & 0.17 & 0.13 & 0.28 & -0.12 & -0.28 \\
\hline
\end{tabular}




\begin{tabular}{|c|c|c|c|c|c|c|c|c|c|c|c|c|c|c|}
\hline & & $* *$ & & & $* *$ & & $*$ & & & $*$ & & $* *$ & & $* * *$ \\
\hline $\mathbf{L M}$ & 0.82 & 0.68 & 0.55 & 0.39 & 0.21 & 0.76 & 0.58 & 0.61 & 0.60 & 0.74 & 0.67 & 0.54 & -0.03 & -0.17 \\
$\mathbf{( K g )}$ & $* * *$ & $* * *$ & $* * *$ & $* * *$ & $* *$ & $* * *$ & $* * *$ & $* * *$ & $* * *$ & $* * *$ & $* * *$ & $* * *$ & $*$ \\
\hline $\mathbf{S M I}$ & 0.61 & 0.60 & 0.35 & 0.33 & 0.29 & 0.61 & 0.53 & 0.45 & 0.49 & 0.60 & 0.52 & 0.40 & 0.01 & -0.20 \\
$\left(\mathbf{k g} / \mathbf{m}^{2}\right)$ & $* * *$ & $* * *$ & $* * *$ & $* * *$ & $* * *$ & $* * *$ & $* * *$ & $* * *$ & $* * *$ & $* * *$ & $* * *$ & $* * *$ & $* *$ \\
\hline
\end{tabular}

$\mathrm{BMI}$, body mass index; FM, fat mass; LM, lean mass; SMI, skeletal muscle index; WB, whole body; BMC, bone mineral content; BMD, bone mineral density; TBS, trabecular bone score; L1-L4, Lumbar spine; TH, total hip; FN, femoral neck; CSA, cross-sectional area; CSMI, crosssectional moment of inertia; Z, section modulus; BR, buckling ratio; SI, strength index. ${ }^{*} p<0.05 .{ }^{* *} p<0.01 .{ }^{* * *} p<0.001$. 
Table 4: Multiple Linear Regressions in Men

\begin{tabular}{|c|c|c|c|}
\hline $\operatorname{Men}(n=129)$ & Coefficient \pm SE & $t$ value & $p$ value \\
\hline \multicolumn{4}{|c|}{ Dependent variable: WB BMC $\left(R^{2}=0.645\right)$} \\
\hline Constant & $1105.120 \pm 245.364$ & 4.504 & $<0.001$ \\
\hline $\mathrm{SMI}\left(\mathrm{kg} / \mathrm{m}^{2}\right)$ & $210.487 \pm 29.734$ & 7.079 & \\
\hline Fat Mass (kg) & $1.335 \pm 2.462$ & 0.542 & 0.589 \\
\hline \multicolumn{4}{|c|}{ Dependent variable: WB BMD $\left(R^{2}=0.535\right)$} \\
\hline Constant & $0.747 \pm 0.0804$ & 9.294 & $<0.001$ \\
\hline $\mathrm{SMI}\left(\mathrm{kg} / \mathrm{m}^{2}\right)$ & $0.0527 \pm 0.00974$ & 5.411 & $<0.001$ \\
\hline Fat Mass (kg) & $0.000186 \pm 0.00080$ & 0.231 & 0.818 \\
\hline \multicolumn{4}{|c|}{ Dependent variable: L1-L4 BMC $\left(R^{2}=0.364\right)$} \\
\hline Constant & $31.125 \pm 11.54$ & 2.695 & 0.008 \\
\hline $\mathrm{SMI}\left(\mathrm{kg} / \mathrm{m}^{2}\right)$ & $5.271 \pm 1.391$ & 3.791 & $<0.001$ \\
\hline Fat Mass (kg) & 0.132 & -1.517 & 0.132 \\
\hline \multicolumn{4}{|c|}{ Dependent variable: L1-L4 BMD $\left(R^{2}=0.351\right)$} \\
\hline Constant & $0.745 \pm 0.117$ & 6.389 & $<0.001$ \\
\hline $\mathrm{SMI}\left(\mathrm{kg} / \mathrm{m}^{2}\right)$ & $0.0556 \pm 0.0141$ & 3.953 & $<0.001$ \\
\hline Fat Mass (kg) & $-0.00188 \pm 0.00116$ & -1.619 & 0.108 \\
\hline \multicolumn{4}{|c|}{ Dependent variable: L1-L4 TBS $\left(R^{2}=0.350\right)$} \\
\hline Constant & $1.103 \pm 0.0824$ & 13.397 & $<0.001$ \\
\hline $\mathrm{SMI}\left(\mathrm{kg} / \mathrm{m}^{2}\right)$ & $0.0395 \pm 0.00994$ & 3.978 & $<0.001$ \\
\hline
\end{tabular}




\begin{tabular}{|c|c|c|c|}
\hline Fat Mass (kg) & $-0.00212 \pm 0.000823$ & -2.579 & 0.011 \\
\hline \multicolumn{4}{|c|}{ Dependent variable: $\mathrm{TH}$ BMC $\left(R^{2}=0.632\right)$} \\
\hline Constant & $7.734 \pm 4.133$ & 1.872 & 0.064 \\
\hline $\mathrm{SMI}\left(\mathrm{kg} / \mathrm{m}^{2}\right)$ & $3.567 \pm 0.501$ & 7.127 & $<0.001$ \\
\hline Fat Mass (kg) & $0.00108 \pm 0.0413$ & 0.0261 & \\
\hline \multicolumn{4}{|c|}{ Dependent variable: $\mathrm{TH}$ BMD $\left(R^{2}=0.479\right)$} \\
\hline Constant & $0.600 \pm 0.0995$ & 6.034 & $<0.001$ \\
\hline $\mathrm{SMI}\left(\mathrm{kg} / \mathrm{m}^{2}\right)$ & $0.0573 \pm 0.0121$ & 4. & $<0.001$ \\
\hline Fat Mass (kg) & $0.0000657 \pm 0.000995$ & & 0.947 \\
\hline \multicolumn{4}{|c|}{ Dependent variable: $\mathrm{FN} \mathrm{BMC}\left(R^{2}=0.531\right)$} \\
\hline Constant & $1.705 \pm 0.716$ & 2.380 & 0.019 \\
\hline $\mathrm{SMI}\left(\mathrm{kg} / \mathrm{m}^{2}\right)$ & $0.477 \pm 0.0868$ & 5.500 & $<0.001$ \\
\hline Fat Mass (kg) & $-0.0000440 \pm 0.00716$ & -0.00615 & 0.995 \\
\hline \multicolumn{4}{|c|}{ Dependent variable: FN BMD $\left(R^{2}=0.490\right)$} \\
\hline Constant & $0.538 \pm 0.107$ & 5.040 & $<0.001$ \\
\hline $\mathrm{SMI}\left(\mathrm{kg} / \mathrm{m}^{2}\right)$ & $0.0653 \pm 0.0129$ & 5.047 & $<0.001$ \\
\hline Fat Mass (kg) & $-0.000231 \pm 0.00107$ & -0.217 & 0.829 \\
\hline \multicolumn{4}{|c|}{ Dependent variable: FN CSA $\left(R^{2}=0.586\right)$} \\
\hline Constant & $53.379 \pm 19.178$ & 2.783 & 0.006 \\
\hline $\mathrm{SMI}\left(\mathrm{kg} / \mathrm{m}^{2}\right)$ & $16.252 \pm 2.323$ & 6.997 & $<0.001$ \\
\hline Fat Mass (kg) & $-0.245 \pm 0.192$ & -1.278 & 0.204 \\
\hline
\end{tabular}




\begin{tabular}{|c|c|c|c|}
\hline \multicolumn{4}{|c|}{ Dependent variable: FN CSMI $\left(R^{2}=0.549\right)$} \\
\hline Constant & $-2773.708 \pm 2999.326$ & -0.925 & 0.357 \\
\hline $\mathrm{SMI}\left(\mathrm{kg} / \mathrm{m}^{2}\right)$ & $2349.293 \pm 363.278$ & 6.467 & $<0.001$ \\
\hline Fat Mass (kg) & $-43.238 \pm 29.984$ & -1.442 & 0.152 \\
\hline \multicolumn{4}{|c|}{ Dependent variable: $\mathrm{FN} \mathrm{Z}\left(R^{2}=0.606\right)$} \\
\hline Constant & $-92.141 \pm 192.140$ & -0.480 & 0.633 \\
\hline $\mathrm{SMI}\left(\mathrm{kg} / \mathrm{m}^{2}\right)$ & $121.803 \pm 23.286$ & 5.231 & $<0.001$ \\
\hline Fat Mass (kg) & $-2.694 \pm 2.042$ & -1.319 & 0.193 \\
\hline \multicolumn{4}{|c|}{ Dependent variable: $\mathrm{BR}\left(R^{2}=0.272\right)$} \\
\hline Constant & $8.246 \pm 2.562$ & 3.218 & 0.002 \\
\hline $\mathrm{SMI}\left(\mathrm{kg} / \mathrm{m}^{2}\right)$ & $-0.430 \pm 0.310$ & -1.386 & 0.172 \\
\hline Fat Mass (kg) & $0.0546 \pm 0.0271$ & 2.012 & 0.049 \\
\hline \multicolumn{4}{|c|}{ Dependent variable: FN SI $\left(R^{2}=0.571\right)$} \\
\hline Constant & \pm 0.258 & 6.447 & $<0.001$ \\
\hline $\mathrm{SMI}\left(\mathrm{kg} / \mathrm{m}^{2}\right)$ & $0.0417 \pm 0.0312$ & 1.334 & 0.185 \\
\hline Fat Mass (kg) & $-0.0175 \pm 0.00258$ & -6.775 & $<0.001$ \\
\hline
\end{tabular}

$\mathrm{WB}$, whole body; $\mathrm{BMC}$, bone mineral content; $\mathrm{BMD}$, bone mineral density; TBS, trabecular bone score; L1-L4, Lumbar spine; TH, total hip; FN, femoral neck; CSA, cross-sectional area; CSMI, cross-sectional moment of inertia; Z, section modulus; BR, buckling ratio; SI, strength index; SMI, skeletal muscle index. 
Table 5: Multiple Linear Regressions in Women

\begin{tabular}{|c|c|c|c|}
\hline Women $(n=206)$ & Coefficient \pm SE & $t$ value & $p$ value \\
\hline \multicolumn{4}{|c|}{ Dependent variable: WB BMC $\left(R^{2}=0.613\right)$} \\
\hline Constant & $1074.848 \pm 111.296$ & 9.658 & \\
\hline $\mathrm{SMI}\left(\mathrm{kg} / \mathrm{m}^{2}\right)$ & $180.452 \pm 22.062$ & 8.179 & $<0.001$ \\
\hline Fat Mass (kg) & $-0.623 \pm 2.717$ & -0.229 & 0.819 \\
\hline \multicolumn{4}{|c|}{ Dependent variable: WB BMD $\left(R^{2}=0.609\right)$} \\
\hline Constant & $0.732 \pm 0.0345$ & & $<0.001$ \\
\hline $\mathrm{SMI}\left(\mathrm{kg} / \mathrm{m}^{2}\right)$ & $0.0536 \pm 0.00684$ & 7.837 & $<0.001$ \\
\hline Fat Mass (kg) & $0.000122 \pm 0.000$ & 0.145 & 0.885 \\
\hline \multicolumn{4}{|c|}{ Dependent variable: L1-L4 BMC $\left(R^{2}=0.358\right)$} \\
\hline Constant & $38.165 \pm 4.113$ & 9.280 & $<0.001$ \\
\hline $\mathrm{SMI}\left(\mathrm{kg} / \mathrm{m}^{2}\right)$ & \pm 0.804 & 4.026 & $<0.001$ \\
\hline Fat Mass (kg) & $0.00369 \pm 0.0986$ & 0.0374 & 0.970 \\
\hline \multicolumn{4}{|c|}{ Dependent variable: $\mathrm{L} 1-\mathrm{L} 4 \mathrm{BMD}\left(R^{2}=0.336\right)$} \\
\hline Constant & $0.891 \pm 0.0528$ & 16.895 & $<0.001$ \\
\hline $\mathrm{SMI}\left(\mathrm{kg} / \mathrm{m}^{2}\right)$ & $0.0383 \pm 0.0104$ & 3.694 & $<0.001$ \\
\hline Fat Mass (kg) & $0.0000778 \pm 0.00127$ & 0.0614 & 0.951 \\
\hline \multicolumn{4}{|c|}{ Dependent variable: L1-L4 TBS $\left(R^{2}=0.294\right)$} \\
\hline Constant & $1.260 \pm 0.0420$ & 30.017 & $<0.001$ \\
\hline
\end{tabular}




\begin{tabular}{|c|c|c|c|}
\hline $\mathrm{SMI}\left(\mathrm{kg} / \mathrm{m}^{2}\right)$ & $0.0233 \pm 0.00832$ & 2.803 & 0.006 \\
\hline Fat Mass (kg) & $0.000533 \pm 0.00102$ & 0.520 & 0.604 \\
\hline \multicolumn{4}{|c|}{ Dependent variable: $\mathrm{TH}$ BMC $\left(R^{2}=0.620\right)$} \\
\hline Constant & $8.194 \pm 1.884$ & 4.350 & $<0.001$ \\
\hline $\mathrm{SMI}\left(\mathrm{kg} / \mathrm{m}^{2}\right)$ & $3.317 \pm 0.372$ & 8.909 & $<0,001$ \\
\hline Fat Mass (kg) & $-0.0508 \pm 0.0458$ & -1.110 & 0.268 \\
\hline \multicolumn{4}{|c|}{ Dependent variable: TH BMD $\left(R^{2}=0.534\right)$} \\
\hline Constant & $0.566 \pm 0.0475$ & & $<0.001$ \\
\hline $\mathrm{SMI}\left(\mathrm{kg} / \mathrm{m}^{2}\right)$ & $0.0655 \pm 0.00940$ & & $<0.001$ \\
\hline Fat Mass (kg) & $-0.000762 \pm 0.00116$ & -0.659 & 0.511 \\
\hline \multicolumn{4}{|c|}{ Dependent variable: FN BMC $\left(R^{2}=0.461\right)$} \\
\hline Constant & $2.082 \pm 0.341$ & 6.104 & $<0.001$ \\
\hline $\mathrm{SMI}\left(\mathrm{kg} / \mathrm{m}^{2}\right)$ & $0.391 \pm 0.0676$ & 5.791 & $<0.001$ \\
\hline Fat Mass (kg) & \pm 0.00833 & -0.633 & 0.528 \\
\hline \multicolumn{4}{|c|}{ Dependent variable: FN BMD $\left(R^{2}=0.498\right)$} \\
\hline Constant & $0.533 \pm 0.0538$ & 9.914 & $<0.001$ \\
\hline $\mathrm{SMI}\left(\mathrm{kg} / \mathrm{m}^{2}\right)$ & $0.0672 \pm 0.0107$ & 6.304 & $<0.001$ \\
\hline Fat Mass (kg) & $-0.000701 \pm 0.00131$ & -0.534 & 0.594 \\
\hline \multicolumn{4}{|c|}{ Dependent variable: FN CSA $\left(R^{2}=0.603\right)$} \\
\hline Constant & $56.158 \pm 8.928$ & 6.290 & $<0.001$ \\
\hline $\mathrm{SMI}\left(\mathrm{kg} / \mathrm{m}^{2}\right)$ & $13.422 \pm 1.770$ & 7.584 & $<0.001$ \\
\hline
\end{tabular}




\begin{tabular}{|c|c|c|c|}
\hline Fat Mass (kg) & $0.0717 \pm 0.218$ & 0.329 & 0.743 \\
\hline \multicolumn{4}{|c|}{ Dependent variable: FN CSMI $\left(R^{2}=0.530\right)$} \\
\hline Constant & $210.623 \pm 1213.980$ & 0.173 & 0.862 \\
\hline $\mathrm{SMI}\left(\mathrm{kg} / \mathrm{m}^{2}\right)$ & $1432.812 \pm 240.646$ & 5.954 & $<0.001$ \\
\hline Fat Mass (kg) & $21.243 \pm 29.641$ & 0.717 & \\
\hline \multicolumn{4}{|c|}{ Dependent variable: FN Z $\left(R^{2}=0.454\right)$} \\
\hline Constant & $316.355 \pm 99.070$ & 3.193 & 0.002 \\
\hline $\mathrm{SMI}\left(\mathrm{kg} / \mathrm{m}^{2}\right)$ & $24.732 \pm 21.089$ & 1.173 & 0.244 \\
\hline Fat Mass (kg) & $5.048 \pm 2.252$ & & 0.028 \\
\hline \multicolumn{4}{|c|}{ Dependent variable: $\mathrm{BR}\left(R^{2}=0.276\right)$} \\
\hline Constant & $2.795 \pm 3.692$ & 0.757 & 0.451 \\
\hline $\mathrm{SMI}\left(\mathrm{kg} / \mathrm{m}^{2}\right)$ & $1.300 \pm 0.786$ & 1.655 & 0.102 \\
\hline Fat Mass (kg) & $-0.178 \pm 0.0839$ & -2.117 & 0.037 \\
\hline \multicolumn{4}{|c|}{ Dependent variable: FN SI $\left(R^{2}=0.298\right)$} \\
\hline Constant & $1.995 \pm 0.182$ & 10.967 & $<0.001$ \\
\hline $\mathrm{SMI}\left(\mathrm{kg} / \mathrm{m}^{2}\right)$ & $0.00233 \pm 0.0361$ & 0.0646 & 0.949 \\
\hline Fat Mass (kg) & $-0.0145 \pm 0.00444$ & -3.275 & 0.001 \\
\hline
\end{tabular}

WB, whole body; BMC, bone mineral content; BMD, bone mineral density; TBS, trabecular bone score; $L 1-L 4$, Lumbar spine; $T H$, total hip; FN, femoral neck; CSA, cross-sectional area; CSMI, cross-sectional moment of inertia; $\mathrm{Z}$, section modulus; BR, buckling ratio; SI, strength index; SMI, skeletal muscle index. 